Discussion Paper No. 08-109

\title{
The Role of Creative Industries in Industrial Innovation
}

Kathrin Müller, Christian Rammer, and Johannes Trüby

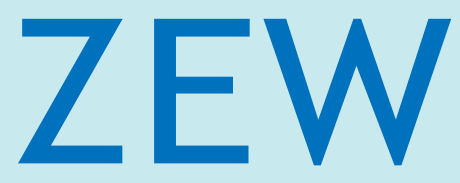

Zentrum für Europäische Wirtschaftsforschung $\mathrm{GmbH}$

Centre for European

Economic Research 
Discussion Paper No. 08-109

\title{
The Role of Creative Industries in Industrial Innovation
}

\author{
Kathrin Müller, Christian Rammer, \\ and Johannes Trüby
}

Download this ZEW Discussion Paper from our ftp server:

ftp://ftp.zew.de/pub/zew-docs/dp/dp08109.pdf

Die Discussion Papers dienen einer möglichst schnellen Verbreitung von neueren Forschungsarbeiten des ZEW. Die Beiträge liegen in alleiniger Verantwortung der Autoren und stellen nicht notwendigerweise die Meinung des ZEW dar.

Discussion Papers are intended to make results of ZEW research promptly available to other economists in order to encourage discussion and suggestions for revisions. The authors are solely responsible for the contents which do not necessarily represent the opinion of the ZEW. 


\section{Non-technical Summary}

The paper empirically analyses the role of Creative Industries in affecting an economy's innovation performance. We distinguish three such roles: First, Creative Industries are a major source of innovative ideas and thus contribute to an economy's innovative potential and the generation of new products and services. Secondly, they offer services which may be inputs to innovative activities of other enterprises and organisations within and outside the creative industries. Thirdly, Creative Industries are intensive users of technology and often demand adaptations and new developments of technology, providing innovation impulses to technology producers.

Creative Industries are defined as those economic activities that strongly rest on individual creativity, skill and talent and predominantly produce intellectual property (in contrast to material goods or immediately consumable services). In order to identify enterprises in the Creative Industries, we combine a sector classification approach (as used by most authors so far) with an analysis of an enterprise's degree of creativity in terms of creativity of employees, creativity of products, and creativity of processes. We define creative enterprises as those belonging to a Creative Industry sector and predominantly conducting creative economic activities.

The empirical study is based on a survey of more than 2,000 creative enterprises from Austria. We show that the creative industries are not only - by definition - a source of creativity, but they also show a strong performance in technological innovation and thus directly contribute to the level of industrial innovation in the economy in terms of technologically new products, new processes and results of own R\&D efforts. They support innovation in a variety of other sectors through creative inputs, such as ideas for new products (i.e. innovation content), supplementary products and services (such as software) or marketing support for product innovations. What is more, they are also an important user of new technology and demand innovations from technology producers, particularly information and communication technologies. Own innovative activities are a key driver for supporting innovation. Creative industries are no homogenous sector, however. While software and advertising show the strongest links to industrial innovation, architecture and content providers contribute rather little to industrial innovation. A main barrier to fully utilising the innovative potential of this sector is the lack of time at the side of creative entrepreneurs which reflects the small average 
firm size and the high share of sole traders. Innovation policy in support of creative industries should thus design programmes that are suitable for micro firms. 


\section{Das Wichtigste in Kürze}

In diesem Aufsatz wird der Beitrag der „Creative Industries“ zur Innovationstätigkeit in einer Volkswirtschaft analysiert. Drei Formen solcher Beiträge werden dabei unterschieden: Erstens die eigenen Innovationsaktivitäten der Creative Industries im Hinblick auf die Hervorbringung neuer Produkte und den Einsatz neuer Technologien, zweitens die Unterstützung von Innovationsaktivitäten anderer Unternehmen durch die Bereitstellung von kreativen Leistungen, sowie drittens die Nachfrage nach neuen Technologien und dadurch die Weitergabe von Innovationsimpulsen an die Technologieproduzenten.

Unter „Creative Industries“ werden all jene wirtschaftlichen Aktivitäten verstanden, die wesentlich auf den Einsatz von Kreativität, persönlichen Fähigkeiten und Talenten der Mitarbeiter beruhen und „intellektuelle Güter“ hervorbringen (im Gegensatz zur Herstellung von materiellen Waren oder von direkt konsumierten Dienstleistungen). Um Unternehmen zu identifizieren, die den „Creative Industries“ angehören, wird sowohl die Wirtschaftszweigzugehörigkeit eines Unternehmens (d.h. die Zugehörigkeit zu einer Kreativbranche) als auch das Ausmaß an Kreativität, mit dem das Marktangebot des jeweiligen Unternehmens erstellt wird (in Hinblick auf die Kreativität der Mitarbeiter, die Kreativität der Produkte und die Kreativität der Prozesse) berücksichtigt. „Kreative Unternehmen“ sind solche, die sowohl einer Kreativbranche angehören als auch ihre Leistungen überwiegend kreativ erbringen.

Die empirische Untersuchung beruht auf einer Befragung von mehr als 2.000 kreativen Unternehmen in Österreich. Es zeigt sich, dass die „Creative Industries“ nicht nur - per definitionem - eine Quelle für Kreativität sind, sondern dass sie auch in bedeutenden Umfang technologische Innovationen - d.h. neue Produkte und Prozesse - hervorbringen und selbst Forschung und Entwicklung betreiben. Bei diesen Imnovationsindikatoren erreichen sie ähnliche Werte wie die forschungsintensive Industrie und tragen somit direkt zur Innovationsleistung einer Volkswirtschaft bei. Außerdem unterstützen Kreative Unternehmen Innovationen in einer Vielzahl anderer Sektoren, sei es durch Ideen für neue Produkte, ergänzende kreative Dienstleistungen oder die Vermarktung von neuen Produkten. Kreative Unternehmen sind außerdem ein wichtiger Nutzer neuer Technologien, vor allem von IuKTechnologien. Starke eigene Innovationsaktivitäten sind dabei ein wichtiger Erfolgsfaktor für die Unterstützung von Innovationen in anderen Unternehmen. Die „Creative Industries“ sind 
gleichzeitig ein heterogener Wirtschaftsbereich. Während Bereiche wie Software, Werbung, Beratung und technische Dienste besonders starke Innovationsbeiträge für andere Branchen liefern, leisten Architektur und Content nur wenig Innovationsunterstützung. Eine wesentliche Barriere für die volle Nutzung des innovativen Potenzials der „Creative Industries“ ist die Kleinheit der Unternehmen, wodurch die zeitlichen und finanziellen Ressourcen eng begrenzt sind. Eine Innovationspolitik zur Förderung der „Creative Industries“ sollte daher insbesondere an der Innovationsfähigkeit von sehr kleinen Unternehmen ansetzen. 


\title{
The Role of Creative Industries in Industrial Innovation
}

\author{
Kathrin Müller, Christian Rammer, and Johannes Trüby \\ Centre for European Economic Research (ZEW)
}

\begin{abstract}
This paper analyses the role of creative industries in affecting an economy's innovation performance. We conducted a survey of more than 2,000 creative industry enterprises from Austria which are defined by a combination of sector affiliation and the degree of creativity of the services they offer. We show that the creative industries are among the most innovative sectors in the economy. They support innovation in a variety of other sectors through creative inputs, such as ideas for new products (i.e. innovation content), supplementary products and services (such as software) or marketing support for product innovations. What is more, they are also an important user of new technology and demand innovations from technology producers, particularly information and communication technologies. Own innovative activities are a key driver for supporting innovation. Creative industries are no homogenous sector, however. While software and advertising show the strongest links to industrial innovation, architecture and content providers contribute rather little to industrial innovation. A main barrier to fully utilising the innovative potential of this sector is the lack of time at the side of creative entrepreneurs which reflects the small average firm size and the high share of sole traders. Innovation policy in support of creative industries should thus design programmes that are suitable for micro firms.
\end{abstract}

Keywords:

JEL-Classification:

Acknowledgements:

Corresponding author: Christian Rammer

Department of Industrial Economics and International Management

European Economic Research (ZEW)

P.O. Box 1034 43, D-68034 Mannheim, Germany

Phone: +49/621/1235-184, Fax: +49/621/1235-170

rammer@zew.de

Creative Industries, Innovation, R\&D, Inter-sector Interaction, Innovation Policy

L82, L86, 031, Z1

The authors would like to thank Helmut Gassler, Peter Georgieff, Simone Kimpeler and Getraud Leimüller for their contributions to the survey design, as well as Georg Licht and Bettina Peters for comments on an early version of this paper. 


\section{Introduction $^{1}$}

The Creative Industries have attracted an increasing number of researchers in the field of economics. Responding to the fast growth of the industry over the past two decades, many studies were dealing with the contribution of Creative Industries to the economy, particularly in terms of employment, regional development and urban dynamics (see Andari et al., 2007; Cooke and Schwartz, 2007; OECD, 2006). Very recently, the role of innovation in the creative industries was studied in more detail. One group of studies focuses on innovation activities in enterprises that belong to the Creative Industries (see Miles and Green, 2008; Wilkinson, 2007; Stoneman, 2007; Handke, 2004, 2006; Galenson, 2006; Green et al., 2007) while some other studies are concerned with the role of Creative Industries in contributing to innovation in the wider economy, particularly with regard to inputs from the creative industries that may be used in innovation processes in other industries (see Bakhshi et al., 2008).

Our paper is related to both strands of research on innovation in the Creative Industries. Its main aim is to enlarge our understanding of how the creative industry affects an economy's innovation activities, both by their own activities and by triggering and supporting innovation in other sectors. We distinguish three roles of Creative Industries as being part of a (national) innovation system: First, Creative Industries are by definition a major source of innovative ideas and thus contribute to an economy's innovative potential and the generation of new products and services. Secondly, Creative Industries offer services which may be inputs to innovative activities of other enterprises and organisations within and outside the creative industries. Thirdly, Creative Industries are intensive users of technology and often demand adaptations and new developments of technology, providing innovation impulses to technology producers.

\footnotetext{
${ }^{1}$ This paper has originated from a broader study on the role of creative industries as part of an innovation system which was funded by the initiative "creative industries austria” within the Austrian Chamber of Commerce. The full report is available in German language (see Georgieff et al., 2008; ARGE Kreativwirtschaft Austria, 2008).
} 
Our study is closely linked to the empirical literature on Creative Industries though it deviates from some of the standard concepts. First, we focus only on commercial for-profit activities, i.e. omitting public organisations and private non-profit organisations. Secondly, we define Creative Industries by a two-stage approach. In a first step, we identify a list of creative industry sectors that is strongly in line with the UK's Department for Culture, Media and Sport (DCMS, 1998) list, extended by two sectors (consulting/training and engineering services). In a second step, enterprises are classified according to the creative nature of the way they produce and deliver their services. Enterprises that belong to a creative industry sector and offer services based on own creative activities are called "creative enterprises" and are the focus of this study.

The main part of the paper presents results from a survey of more than 2,000 creative enterprises from Austria and their innovation activities. In the following section 2 we discuss the ways how Creative Industries may impact on innovation in other sectors. The data used and key underlying definitions are presented in section 3. Section 4 discusses key results on innovation activities in creative enterprises and some of their determinants. Section 5 deals with the contribution of Creative Industries to innovation in other sectors. In the final section 6 we turn to the policy implications of our research, particularly focussing on the way policy may intervene to fully utilise the innovative potential of creative enterprises.

\section{Creative Industries and Industrial Innovation}

The Creative Industries are regarded as one of the most promising fields of economic activity in highly developed economies, having a great potential to contribute to wealth and job creation. Their activities rest upon individual creativity, skill and talent, i.e. factors of production for which high-income countries have a comparative advantage. In contrast to most other industries, their main output is intellectual property rather than material goods or immediately consumed services. Demand for such immaterial output, which is often tailored to the specific requirements and preferences of individual users, is likely to increase with growing per-capita income. Being a cross-sectional industry which serves a large number of other sectors as well as public organisations and consumers, the creative industries profit from 
a diversified mix of customers and may stimulate growth in a variety of other sectors by providing creative inputs.

Besides the contribution to growth and employment, another key interest in research and policy making is the role of the Creative Industries for an economy's innovation performance. We assume that this role is twofold. On the one hand, the Creative Industries may develop and introduce innovations as part of their business activities, thus directly contributing to an economy's innovative output. Such innovations include new products and services offered to their customers (product innovation) as well as new technologies, procedures and routines within their business that raise efficiency or quality of their output (process innovation). An example for product innovation may be a new marketing approach offered by an advertising company which has not been used by this company before. On the other hand, the Creative Industries support innovation in other industries through creative inputs. These inputs can either be downstream, i.e. creativity produced in the Creative Industries is used by customers in their innovative efforts, or upstream, i.e. the Creative Industries demand innovative inputs from their suppliers (e.g. technology producers). Creative inputs need not necessarily coincide with the Creative Industries’ own product innovations but may also relate to standard (i.e. non-innovative) activities of creative enterprises.

Innovation performance in the Creative Industries has been measured through different approaches. One way is to apply concepts used to measure innovation in manufacturing or other industries, often relying on the methodological recommendations laid down in the OECD and Eurostat's (2005) “Oslo Manual” on collecting and interpreting innovation data. Bakhshi et al. (2008), Miles and Green (2008) and Wilkinson (2007) show results of such an exercise based on UK data. Another way is to capture the specificities of innovation in enterprises producing creative services by developing separate concepts of innovation, such as aesthetic or "soft" innovation (Stoneman, 2007), content innovation (Handke, 2004; 2006), artistic innovation (Galenson, 2006) or case study based approaches (Miles and Green, 2008; Green et al., 2007). The former approach clearly benefits from a high level of comparability with innovation data from other sectors and thus allows to evaluating the Creative Industries' innovation performance compared to other industries. The latter approach is more able to fully capture innovation in the Creative Industries, however, particularly with respect to types of innovative activity that may be hidden by applying traditional measures (see Miles and 
Green, 2008). This is particularly true for creative products and services that are highly customised and are designed individually for each customer, such as graphic design, architecture or performing arts. These customised products may be viewed as "aesthetic innovations" since their appearance differs from that of any other product produced by the same producer before. From the designer's, architect's or artist's point of view, they are not new products, however, since they simply represent their standard product.

In this study, we apply the former approach to measure innovation in the Creative Industries, using standard definitions and indicators of innovation activity and output that comply with the concepts laid down in the Oslo Manual and guiding the Community Innovation Surveys (CIS) coordinated by Eurostat. Doing so, we are able to directly compare innovation performance of creative enterprises with that of companies from other sectors. At the same time, we attempt to take into account the specific nature of the Creative Industry when it comes to their contribution to innovation in other sectors. We explore our approach below.

The Creative Industries' contribution to innovation in other sectors of the economy is strongly linked to the concept of open innovation (see Chesbrough, 2002; Laursen and Salter, 2006). Successful innovation most often requires the combination of a firm's own innovative resources with external inputs. External inputs can range from external knowledge (e.g. technology developed by other organisations) or specialised research and development (R\&D) services to ideas for innovations generated by suppliers, competitors or customers (see von Hippel, 1988), including co-operation with partners for developing innovations. As producers of intellectual property, the Creative Industries may be a particularly attractive source of external knowledge for innovating firms. They offer a diverse bundle of creative products and services which can be integrated into the innovation process of other businesses. These innovation supporting or innovation accompanying products can range from ideas for innovations to $\mathrm{R} \& \mathrm{D}$ support and product design. Furthermore, specific software can be developed to fulfil the needs of new products or processes. However, it could also be a new marketing strategy or engineering services for more efficient production techniques, tailored to the particular needs of the innovating company. Consultancies can offer new training approaches in order to fully extract the creative potential of the workforce whereas architects can provide concepts for creativity-enhancing buildings and workplaces. 
Another important concept for studying innovation effects of the Creative Industries is the interaction between users and producers in developing and marketing innovation (Fagerberg, 1995), especially with regard to users that demand certain innovations that will later become a global standard (see Beise, 2004). Creative Industries are often at the forefront of applying new technological devices, particularly in the area of information and communication technologies (ICT). Their demand for new applications can provide a major stimulus for innovation at the side of technology producer. In general, the most innovative firms are also often those that are most demanding in terms of innovative products supplied by upstream industries. The demand side significance of the Creative Industries can be seen from its share in total value added, which exceeds 5 percent in most economies (see OECD, 2006).

Creative Industries may also support innovation in the wider economy without direct interaction. A key mechanism to do so is the mobility of the workforce, in particular when people find new jobs outside the creative industries and take their ideas, knowledge and creative potential with them and use it in other industries. Skill is maybe the most crucial input to industrial innovation (see Leiponen, 2005), and skilled and talented people are a key element for a firm's potential to absorb external knowledge (see Cohen and Levinthal, 1989; 1990). A crucial part of the innovation stimulating and supporting potential of the Creative Industries certainly lies within the human capital of their workforce.

Another role of the Creative Industries in industrial innovation is to link academia and the business world. On the one hand, the Creative Industries are an important employer of graduates who want to apply their knowledge and creativity acquired during their studies, to commercial purposes. On the other hand employees in the Creative Industries regularly have close ties to their former professors and fellow alumni which facilitate to establish cooperation. Such cooperation often contributes to the commercial utilisation of scientific findings and approaches.

This view of how the Creative Industries are linked with innovation in other sectors are related the one used so far in the empirical literature. Bakhshi et al. (2008) and Experian (2007) both use measures from input-output accounts and data from the CIS in order to explore the relationship between the Creative Industries and innovation in other sectors. They distinguish between two effects which can influence innovation activities in other sectors. The creative industries' products may be direct inputs into innovation processes and secondly, the 
strong supply chain linkages may facilitate the diffusion of knowledge and ideas between the creative industries and other businesses. They find that there are significant B2B linkages between the Creative Industries and the wider economy and they show that firms with a higher share of inputs from the Creative Industries tend to be more innovative in terms of product innovations. A disadvantage of this approach is that neither information on the knowledge transfer mechanisms nor on the type of supporting activity can be obtained. Furthermore non-market contributions to innovations in other industries and the role of creative industries as customers of highly innovative technology are not accounted for. In this paper, we attempt to fill this gap.

\section{Empirical Approach}

\subsection{Defining the Creative Industries}

Investigating the Creative Industries requires a proper definition of this sector. Throughout the literature different methodologies have been developed in order to delineate the cultural and creative sector in Europe. All these different methodologies can be subsumed by four general approaches: the "Creative Industries approach", the "Copyright Industries” approach, the "Experience Economy” approach and sector specific studies (see European Commission, 2006). In this study, we follow the "Creative Industries" approach, applying a conceptual definition of this sector proposed by the Creative Industries Task Force of DCMS. They describe Creative Industries as "industries which have their origin in individual creativity, skill and talent and which have a potential for wealth and job creation through the generation and exploitation of intellectual property” (DCMS, 1998).

Based on this definition, the DCMS came up with a list of activities that constitute the creative industries, including advertising, architecture, arts and crafts, broadcasting, design and fashion, film, games, music, performing arts, publishing and printing, and software and computer services. Creative Industries may include both activities which have a commercial focus as well as non-profit activities performed by private or public organisations, often including cultural activities such as museums or libraries. Linking this list of activities to industrial classification systems as used by official statistics allows to identifying enterprises 
that belong to the Creative Industries, and the scope of these enterprises' economic activities. This approach is widely followed in the literature (see Higgs et al., 2008, for the UK or OECD, 2006). A main drawback is that there may be a number of businesses within a certain "creative sector" that do not meet the definition of Creative Industries, i.e. their activities do not rest on individual creativity, skill and talent. This is basically because industry classifications are based on the type of good produced, irrespectively of the precise way of production.

We try to overcome this drawback by combining a list based definition with one that characterises the degree of creativity of an enterprise's economic activities. Essentially, we only look at those enterprises within creative industry sectors that produce and deliver products and services in a "creative way”. We distinguish three dimensions of creativity: creativity of individuals, creativity of products, and creativity of processes. Creativity of individuals refers to their ability to generate novelties and respond to challenges by finding new solutions. This type of creativity is closely linked to the artistic or aesthetic talent in the creative process but should be distinguished from skills in terms of qualification and experience acquired through systematic learning or business practice. Creativity of products is related to the degree of uniqueness of a product or service compared to other products and services offered in the market. A creative product has to contain some sort of originality which distinguishes it from other products. While originality or uniqueness may give a product a "creative advantage”, it may suffer at the same time from a lack of reliability, and customers may question the quality since no predecessor products and no past experience in using the product is available. Finally, creativity of processes concerns the way an enterprise delivers its products and services to customers. Designing products and delivery processes in a way to meet the very specific requirements of each customer gives the product another dimension of creativity. This customisation is not necessarily connected to a product's uniqueness since the latter refers to a product's general characteristics while customisation is the process to creatively adjusting products to customer demand.

We assume that an enterprise qualifies for being a "creative enterprises" if it is engaged in a creative industry activity (see below) and at the same time rests its products and services primarily on individual talent, originality of their products and customisation of the delivery 
process. In the following section, we present the way how we measure these three dimensions of creativity empirically.

We use a list of creative industry activities that is based on DCMS' list, though adapted to the specific purpose of our study. We define a core group of Creative Industries that consists of six sectors and covers most of the activities listed by DCMS:

- Content: film, (computer) games, journalism, authors, music, performing arts, photography, sound studios;

- Design: arts and crafts, design and fashion, graphic design, engineering design, web design;

- Architecture: architecture including landscaping and urban planning;

- Advertising: planning, creating and putting in place advertising campaigns, public relations management, market research, advertising services;

- Software: programming and computer services (excluding web design and computer games);

- Publishing: publishing of books, newspapers and other printed matter, including printing services.

We refrain from considering retail activities since they are loosely related to the key definition of Creative Industries and rather focus on linking producers of creative products with consumers. This is in line with the approach suggested by Frontier Economics (2006) who differentiate by various layers of creative activities, regarding retail activities as most distant from the core of the Creative Industries. We do not consider museums, libraries, cinemas, broadcasting and related forms of presenting the outcome of creative work since these are basically transmitting rather than producing creative products, while we fully capturing all activities

We add two further sectors, however, which are often overlooked in analyses of the Creative Industries, though showing a number of similarities with regard to the role of individual talent, creativity and skills as well as the role of producing intellectual property as a base for commercial value: 
- Consultancy: business consulting, including business training and coaching;

- Engineering: all types of engineering services, including industrial R\&D services, but excluding engineering design (which is part of the Design sector).

We focus on enterprises (including sole traders) that conduct commercial activities, i.e. offer products and services which are sold via the market. Our analysis is restricted to domestic enterprises only, and we exclude very large companies (with more than 500 employees) since their innovation behaviour and their innovation-related interaction with other firms may be little representative for the Creative Industries but rather show patterns typical for any large company.

\subsection{Data}

The empirical analysis rests on a survey of creative enterprises from Austria. The survey was designed as a computer-assisted telephone interview (CATI) based on a standardised questionnaire. In order to identify creative enterprises, we drew a stratified random sample of enterprises active in one of the eight creative sectors listed in the section above at the end of the year 2007. At the beginning of the telephone interview, enterprises were asked to characterise their business activity along three dimensions of creativity:

- Do your customers value first of all originality and uniqueness of your products and services, or rather reliability and proven quality?

- Do your business activities primarily rest on qualification and work experience of yourself/your staff or is in rather individual talent that drive your business?

- Does your enterprise primarily offer products and services that are designed specifically for each customer, or do you offer products and services in a similar way for a larger number of customers?

Interviews were performed only with those enterprises stating that at least one creativity dimension (originality/uniqueness of products, individual talent, customer-specific design) was characteristic for their business activity.

The sample was drawn from a database of enterprises provided by the two largest credit rating and business information organisations in Austria, Kreditschutzverband von 1870 and 
Creditreform. Since both organisations together have a market share of close to 100 percent, the merged data represent almost the entire enterprise population in Austria's Creative Industries as far as enterprises with a significant economic activity are concerned, though firms founded very recently are likely to not be fully covered (at the time of drawing the sample, this concerns firms founded in 2005 to 2007). Enterprises were drawn based on their NACE 4-digit code. The sample was stratified by sector (Content/Design, Architecture/Engineering, Advertising, Software, Consultancy), size (sole traders and enterprises with a staff of two or more, including the owner) and region (Vienna metropolitan area and the rest of Austria). The sample was manually checked and corrected for erroneous entries due to miscoding of NACE categories. In this step, non-domestic companies as well as very large companies were excluded from the sample.

The gross sample consisted of 5,847 enterprises, which is about 30 percent of total firm population in the sectors considered. 492 enterprises could not be contacted due to unavailability of a correct telephone number, pointing to business closure. 359 could not be contacted because the contact person, i.e. the business owner or one of the managers, was not available during the eight weeks of field study (January and February 2008). 1,804 enterprises refused to participate in the survey, which is equal to 31 per cent of the gross sample corrected for neutral losses. A total of 2,203 enterprises were contacted and asked the three questions on creativity characteristics. It turned out that just 166 (= 7.6 percent) did not meet the creativity requirements, while 2,037 reported that at least one of the three items do characterise their business activity. ${ }^{2}$ From these, 6 enterprises have been excluded from the sample because their main business activity did not fall into one of the creative industry activities. The resulting net sample consists of 2,031 enterprises. One should know that 37 percent of these creative enterprises are sole traders, and another 27 percent have less than 5 employees (including the owners). Just 16 percent employ 10 or more people. Since some creative enterprises are quite large, the average number of employees is 8.3. 19 percent of all creative enterprises work in the Architecture sector, between 13 and 16 percent belong to Software, Engineering, Consultancy and Advertising each, Content and Design each cover 9

\footnotetext{
${ }^{2}$ Actually, 29 per cent of these enterprises indicated that all three creativity items characterise their business activity, 40 per cent reported two items, and 31 per cent only one item.
} 
percent of all creative enterprises, while Publishing is the smallest creative industry sector (5 percent).

The estimated total population of creative enterprises in Austria at the beginning of 2008 is 19,691, which is roughly 7 per cent of all enterprises in the Austrian business enterprise sector. This figure is calculated from the total number of enterprises within the eight creative industry sectors as contained in the data base of Kreditschutzverband von 1870 and Creditreform, complemented for recently started enterprises not yet contained in the data base $^{3}$ and reduced by the share of enterprises per sector that turned out not to produce in a creative way. This share was lowest in Architecture and Design (below 1 per cent) and highest in Software (13.8 per cent). All survey results reported below were weighted to represent the total population of creative enterprises in Austria.

\section{Innovation Activities of Creative Enterprises}

\subsection{Descriptive Results}

We measure innovation activities of creative enterprises based on the common concepts and definitions laid down in the Oslo Manual (OECD and Eurostat, 2005). We distinguish product and process innovation. A product innovation is a product or service which has not been supplied to the market by the enterprise before. Similarly, a process innovation is a business process for producing or delivering products and services which has not yet been used by the enterprise. Product and process innovations are thus subjective concepts, depending on the viewpoint of an enterprise. In addition, innovations must have been successfully introduced, i.e. they have to be available for purchase in the market, or they must be implemented within the enterprise. While neither product nor process innovation are directly linked to the development of new technology, both concepts are still related to technological change since introducing a new product typically demands some change in the underlying material base of the product or the process to produce and deliver it compared to s firm's "old” products. In

\footnotetext{
${ }^{3}$ This correction is based on analyses on the average time lag between the starting date of a business and the time this business is registered by a credit rating agency, see Almus et al. (2000).
} 
case of process innovation, the link to technology is mostly more direct as a new business process will require at least some changes in production methods or information processing.

Both types of innovations may include novel innovations, i.e. innovations that have not been introduced by any other enterprise before (so-called market novelties), and imitations, i.e. innovations which were copied from an earlier innovator. Innovation and creativity are not necessarily related. Enterprises that innovate through imitating may not require own creative efforts. On the other hand, enterprises may fail to successfully complete innovation projects and may thus not qualify for being an innovator, though having invested heavily into creative efforts. Creativity may thus be viewed as one input to innovation. In this sense, creativity is closely related to the concept of research and experimental development (R\&D). R\&D constitutes one specific form of creative work as it denotes all efforts targeted at generating new knowledge which may be relevant to develop and implement innovations (see OECD, 2002).

Measuring innovation in creative enterprises through standard concepts from innovation statistics is complicated by the fact that essentially all products and services offered by creative enterprises (as defined in this study) are in some way or another innovative since they were either designed specifically for a certain customer's demand, are based unique or separated from other products by a certain degree of originality, or represent the results of individual creative work. Still, not all creative enterprises need to be innovating enterprises automatically. This is obvious with regard to process innovation since new products and services can be developed based on standard technology. In case of products and services, creative enterprises will be non-innovators as long as the types of products and services they offer in the market remain unchanged, even if the products and services themselves contain a significant amount of creative work (e.g. a graphic designer who offers the service of designing title pages of periodicals will be a non-innovator as long as this service is neither changed in its nature nor supplemented or substitute by other types of services, though each title page is unique and highly creative).

Our survey shows that 71 percent of the creative enterprises in Austria are innovators, i.e. they have introduced at least one product or process innovation during a three year time 
period, ${ }^{4} 2005$ to 2007 (see table 1). Product innovators are more frequent than process innovators: 59 percent of the creative enterprises are supplying new products to the market whereas 49 percent have introduced new methods of production. Most innovating creative enterprises have both product and process innovations. Publishing, Advertising, Software, Content and Consultancy sectors report particularly high shares of innovators (77 to 82 per cent). Creative enterprises in the Design and Engineering sectors of the Creative Industries show an average probability to innovate of 71 percent while Architecture is the only sector with a clearly below average share of innovators (53 percent). This low figure is due to a small share of enterprises that introduce both new products and new processes. For enterprises with process innovations only, there are no significant variations among creative industry sectors. Looking at novel product innovations, Publishing and Consultancy sectors report the highest figures, while only a small share of creative enterprises from the Design and Architecture sectors supply their markets with entirely new products.

Table 1: Innovation indicators for creative enterprises in Austria

\begin{tabular}{|c|c|c|c|c|c|c|}
\hline & \multicolumn{5}{|c|}{ Share of enterprises that introduced ... } & \multirow[b]{2}{*}{$\begin{array}{l}\text { Share of } \\
\text { enterprises } \\
\text { conducting } \\
\text { in-house } \\
\text { R\&D }\end{array}$} \\
\hline & $\begin{array}{l}\text { product } \\
\text { innovation } \\
\text { only }\end{array}$ & $\begin{array}{l}\text { both } \\
\text { product } \\
\text { and } \\
\text { process } \\
\text { innovation }\end{array}$ & $\begin{array}{c}\text { process } \\
\text { innovation } \\
\text { only }\end{array}$ & $\begin{array}{c}\text { market } \\
\text { novelties } \\
\text { (= part of } \\
\text { product } \\
\text { innovation) }\end{array}$ & $\begin{array}{l}\text { any type of } \\
\text { innovation }\end{array}$ & \\
\hline Content & 22 & 41 & 13 & 24 & 77 & 21 \\
\hline Design & 22 & 36 & 12 & 12 & 71 & 20 \\
\hline Architecture & 18 & 21 & 14 & 8 & 53 & 24 \\
\hline Advertising & 21 & 44 & 14 & 23 & 80 & 25 \\
\hline Software & 28 & 40 & 10 & 23 & 78 & 46 \\
\hline Publishing & 29 & 40 & 12 & 28 & 82 & 14 \\
\hline $\begin{array}{l}\text { Creative Industries } \\
\text { (core) }\end{array}$ & 23 & 35 & 13 & 18 & 71 & 28 \\
\hline Consultancy & 25 & 42 & 10 & 27 & 77 & 34 \\
\hline Engineering & 17 & 41 & 12 & 25 & 71 & 47 \\
\hline $\begin{array}{l}\text { Creative Industries } \\
\text { (extended) }\end{array}$ & 22 & 37 & 12 & 20 & 71 & 31 \\
\hline
\end{tabular}

All figures show the share (percent) in the total number of creative enterprises. Innovation and R\&D activities refer to activities during 2005 to 2007.

Source: Creative Industry Survey Austria 2008. Weighted data.

\footnotetext{
${ }^{4}$ Innovation statistics use a multiannual reference period in order to capture innovations in sectors with long product and technology cycles, which are likely to result in discontinuous innovation activity, especially among small firms.
} 
31 percent of the creative enterprises in Austria conduct in-house $R \& D$. This figure is driven by two creative sectors, Engineering and Software. Among the creative enterprises in the Content, Design, Architecture and Advertising sectors, only a fifth to a fourth engage in R\&D activities.

In order to evaluate the significance of innovation and R\&D activities in creative enterprises, we compare the figures with those from the Community Innovation Survey (CIS). The most recent survey data available are from the 2005 survey wave and refer to the reference period 2002 to 2004. We compare creative enterprises with enterprises from knowledge-intensive sectors as far as these are covered in the CIS (which is chemical industry including pharmaceuticals, mechanical engineering, electrical industry, vehicle manufacturing, computer services and engineering services) as well as with the total of all sectors covered by CIS. We use innovation data for these sectors from 13 countries in order to avoid country specific effects on innovation behaviour in some sectors. Two sectors from the comparison group - computer services and engineering services - largely overlap with the Software sector and the Architecture and Engineering sectors of the Creative Industries, though the comparison group also includes enterprises which would not have been classified as creative in our survey. Since the CIS is targeted at enterprises with 10 or more employees, we compute figures for the creative enterprises that refer to the same size class.

Creative enterprises turn out to be significantly more innovative than enterprises from other knowledge intensive sectors. Among the creative enterprises with 10 or more employees, 86 percent have introduced product or process innovations within a three year time period, compared to 56 percent among enterprises from knowledge-intensive sectors (see table 2). While the share of creative enterprises with only product innovations and with only process innovations is at the same level as for knowledge-intensive industries, a significantly larger proportion of creative enterprises report both product and process innovations (55 percent) compared to the group of knowledge-intensive sectors (26 percent). The share of novel innovators is markedly higher, too, with 40 percent for the Creative Industries against 27 percent for knowledge-intensive industries. With regard to in-house $R \& D$, differences are less pronounced. While 51 percent of the creative enterprises with 10 or more employees report in-house $\mathrm{R} \& \mathrm{D}$, this share is 45 percent for all knowledge-intensive sectors, but 54 percent for computer services and 52 percent for the chemical industry. 
Table 2: Innovation indicators for the Creative Industries and other knowledge intensive industries (enterprises with 10 or more employees)

\begin{tabular}{|c|c|c|c|c|c|c|}
\hline & $\begin{array}{c}\text { product } \\
\text { innovations } \\
\text { only }\end{array}$ & $\begin{array}{l}\text { Share of en } \\
\text { both } \\
\text { product } \\
\text { and } \\
\text { process } \\
\text { innovation }\end{array}$ & $\begin{array}{l}\text { erprises that i } \\
\text { process } \\
\text { innovation } \\
\text { only }\end{array}$ & $\begin{array}{c}\text { troduced ... } \\
\text { market } \\
\text { novelties } \\
\text { (= part of } \\
\text { product } \\
\text { innovation) }\end{array}$ & $\begin{array}{l}\text { any type of } \\
\text { innovation }\end{array}$ & $\begin{array}{l}\text { Share of } \\
\text { firms } \\
\text { conductin } \\
\text { g in- } \\
\text { house } \\
\text { R\&D }\end{array}$ \\
\hline $\begin{array}{l}\text { Creative Industries } \\
\text { (extended) }\end{array}$ & 20 & 55 & 11 & 40 & 86 & 51 \\
\hline Chemical industry & 17 & 32 & 11 & 31 & 60 & 52 \\
\hline Mechanical engineering & 22 & 25 & 11 & 29 & 59 & 45 \\
\hline Electrical industry & 22 & 27 & 9 & 31 & 58 & 50 \\
\hline Vehicle manufacturing & 11 & 25 & 11 & 22 & 47 & 38 \\
\hline Computer services & 23 & 31 & 8 & 30 & 62 & 54 \\
\hline Engineering services & 12 & 20 & 12 & 18 & 45 & 29 \\
\hline $\begin{array}{l}\text { Knowledge-intensive } \\
\text { sectors }\end{array}$ & 19 & 26 & 10 & 27 & 56 & 45 \\
\hline $\begin{array}{l}\text { Manufacturing and } \\
\text { business services* }\end{array}$ & 10 & 16 & 14 & 14 & 40 & 24 \\
\hline \multicolumn{7}{|c|}{$\begin{array}{l}\text { All figures show the share (percent) in the total number of creative enterprises. Innovation and R\&D activities refer to } \\
\text { activities during } 2005 \text { to } 2007 \text { for Creative Industries, and } 2002 \text { to } 2004 \text { for all other industries. Data for all other industries } \\
\text { are weighted averages for Austria, Belgium, Denmark, Germany, Greece, France, Italy, Luxembourg, Netherlands, Norway } \\
\text { Portugal, Sweden, Spain. } \\
\text { * Manufacturing including mining and energy/water supply, business services including wholesale trade, transport and } \\
\text { communication, financial intermediation, computer services and engineering services. } \\
\text { Source: Creative Industry Survey Austria 2008, Eurostat: CIS4. Weighted data. }\end{array}$} \\
\hline
\end{tabular}

\subsection{Determinants of Innovative Activities in Creative Enterprises}

In order to identify the drivers for innovation activities in creative enterprises we run a set of regression models. They attempt to explain the probability that a creative enterprise introduces product or process innovations or conducts in-house $R \& D$ through a set of explanatory variables that are often used in analyses of innovative behaviour of firms (see Crepon et al., 1998; Cohen, 1995; Acs and Audretsch, 1988; Bhattacharya and Block, 2004). Following this literature, we test for size effects (see Cohen and Klepper, 1996; Acs and Audretsch, 1991; Van Dijk et al., 1997), effects of firm age (see Huergo and Jaumandreu, 2004) and skill effects (see Leiponen, 2005). With respect to skills, we use the share of graduated employees (including the enterprise owners) as well as indicators for the academic subjects.

Specifically to the Creative Industries, we add five variables. A “creativity index" is used to capture the level of an enterprise's creativeness, referring to the three questions on creative characteristics discussed in Section 3.1. On each question, an enterprise had to report whether the characteristic applies completely, mainly or little/not. For computing the index, we 
allocate two points for "completely” and one point for "mainly", thus the index ranges from 1 to 6 (since all enterprises stating little/not on all three items were excluded from the survey).

Three further variables measure networking activities with other creative enterprises. Networking among creative enterprises can increase their innovative potential in different ways. Most creative enterprises are very small and may thus suffer from "liabilities of smallness” (see Brüderl and Preisendörfer, 1998). Limited resources make it difficult to allocate sufficient effort to the various activities needed to run a business. Specialising on a certain creative activity (e.g. designing computer games) and purchasing complementary creative inputs needed to sell a final product (e.g. software programming) may reduce some . We capture this "creative sourcing” strategy by a variable that measures whether an enterprise uses creative supplies from other firms. Small firms will also find it more difficult to build up reputation and signal reliability to their customers, particularly when products are not standardised, contain a high degree of uniqueness and are designed customer-specific. Engaging in networks with other creative enterprises can improve quality signals since potential customers can expect that a failure of one team member in delivering in the right quality and time may be compensated by other members of a creative network. We use a question on whether a creative enterprise develops or delivers products and services together with other creative enterprises to construct two "team work" variables. One dummy variable measures a creative enterprise's involvement in "stable networks" (= a network consisting of the same partners for a longer period of time), while another one measures "flexible networking” (= building a network of partners for a specific situation). Note that an enterprise is assigned to only one of the two types of networking, depending on the dominant type used. The team work variables should also capture positive networking effects on the protection of intellectual property (IP) of each member since networks, particularly stable ones, increase trust and facilitate the establishment of IP protection methods or IP sharing.

Since mobility of people among enterprises within the Creative Industries may be a particular characteristic which can either stimulate or hinder innovation, we calculate an employee mobility index which is the number of employees who either joined or left a creative enterprise within a three year period (2004 to 2007), divided by the number of employees at the end of 2007. Finally, we add a dummy variable for enterprises located in a University 
town in order to control for their specific environment which is often said to promote a creative industry’s development (see Florida, 2002; Scott, 2000).

Dropping firms without full information on all model variables results in a total of 1,998 observations for model estimations. Descriptive statistics on model variables are shown in table A1 in the Appendix.

We run probit regressions for product innovation, process innovation and in-house $R \& D$ separately. For product innovations, we distinguish enterprises that introduced novel products that have not been offered in the relevant market by any other firm before from those with only product imitations, i.e. products which are new to the enterprise, but were offered on the market before by other firms. Table 3 reports the results. There are clear size effects (except for product imitations) while age only affects the probability of introducing product imitations (with younger creative enterprises being more likely to imitate innovations from other enterprises) and the skill level of employees is relevant for conducting in-house R\&D only.

There are very different effects from the academic subject in which employees (including firm owners) graduated: creative enterprises with employees having a natural science, engineering and mathematics/computer science background show significantly higher propensities to introduce process innovations, to introduce market novelties or to conduct in-house R\&D. The probability for introducing market novelties also increases if graduates from law/business/economics are present in an enterprise. There is a strong positive effect from graduates in humanities/cultural sciences on conducting in-house R\&D.

Among the variables specific to creative industries, the creativity index is statistically significant and positive for process innovation, market novelties and in-house R\&D while it exerts a significant negative effect on the probability to introduce product imitations. This result suggests a rather close relationship between creativity and (technological) innovation. The effect is particularly strong for in-house $R \& D$. This indicates that even within the group of creative enterprises the level of creativity is positively associated with the capability of being successful with more challenging types of innovative activities while enterprises with low creative potentials opt for imitation strategies. 
Table 3: Determinants of the probability to introduce process innovations, product innovations and market novelties by creative enterprises: marginal effects of probit regressions

\begin{tabular}{|c|c|c|c|c|c|c|c|c|c|c|}
\hline \multirow[b]{3}{*}{ No. of Employees (log) } & \multirow{2}{*}{\multicolumn{2}{|c|}{$\begin{array}{l}\text { Process } \\
\text { innovation }\end{array}$}} & \multicolumn{6}{|c|}{ Product innovation } & \multirow{2}{*}{\multicolumn{2}{|c|}{$\begin{array}{l}\text { In-house } \\
\text { R\&D }\end{array}$}} \\
\hline & & & \multicolumn{2}{|c|}{ all types } & \multicolumn{2}{|c|}{ imitations } & \multicolumn{2}{|c|}{ novelties } & & \\
\hline & 0.066 & 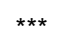 & 0.063 & $\star \star \star *$ & -0.006 & & 0.059 & *** & 0.055 & 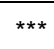 \\
\hline Age (log) & 0.001 & & -0.062 & $\star \star \star *$ & -0.048 & $* * *$ & -0.011 & & 0.010 & \\
\hline Located in a University town (d) & -0.021 & & -0.038 & & 0.005 & & -0.047 & ** & -0.006 & \\
\hline Employee mobility (share) & 0.014 & & 0.035 & $\star \star \star *$ & 0.017 & & 0.018 & ** & 0.017 & \\
\hline Creativity Index & 0.039 & $* * *$ & 0.018 & * & -0.019 & * & 0.034 & $* * *$ & 0.056 & $* * *$ \\
\hline Use of creative inputs (d) & 0.086 & $* \star \star$ & 0.050 & $\star \star$ & -0.022 & & 0.073 & $\star \star \star ~$ & 0.069 & 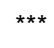 \\
\hline Stable networks (d) & 0.079 & $* *$ & 0.101 & $\star \star \star ~$ & 0.066 & ** & 0.026 & & 0.030 & \\
\hline Flexible networking $(\mathrm{d})$ & 0.016 & & 0.041 & & 0.044 & & 0.001 & & -0.006 & \\
\hline \multicolumn{11}{|c|}{ Academic subjects of graduated employees (d) } \\
\hline Natural science & 0.101 & * & 0.002 & & -0.096 & * & 0.090 & ** & 0.184 & 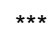 \\
\hline Engineering & 0.100 & $* \star *$ & 0.100 & $\star \star \star *$ & 0.028 & & 0.069 & ** & 0.115 & 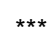 \\
\hline Maths/computer science & 0.073 & & 0.029 & & -0.098 & ** & 0.119 & $\star \star \star ~$ & 0.140 & 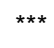 \\
\hline Design & 0.039 & & -0.008 & & 0.045 & & -0.058 & * & 0.119 & *** \\
\hline Law/business/economics & 0.027 & & 0.029 & & -0.048 & * & 0.072 & $\star \star \star ~$ & 0.071 & $\star \star$ \\
\hline Journalism/social sciences & 0.077 & * & 0.067 & & 0.094 & ** & -0.030 & & -0.015 & \\
\hline Humanities/cultural sciences & -0.044 & & 0.082 & * & 0.003 & & 0.061 & * & 0.154 & 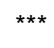 \\
\hline \multicolumn{11}{|l|}{ Sectors (reference: Engineering) (d) } \\
\hline Design & 0.015 & & 0.066 & & 0.134 & 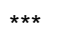 & -0.071 & * & -0.186 & *** \\
\hline Content & 0.050 & & 0.103 & $\star *$ & 0.064 & & 0.049 & & -0.214 & 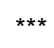 \\
\hline Architecture & -0.164 & 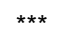 & -0.128 & $\star \star \star ~$ & -0.049 & & -0.094 & $\star \star \star ~$ & -0.209 & 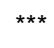 \\
\hline Advertising & 0.005 & & 0.041 & & 0.091 & * & -0.036 & & -0.226 & 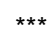 \\
\hline Software & -0.002 & & 0.114 & $\star \star \star$ & 0.124 & 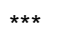 & -0.011 & & 0.008 & \\
\hline Publishing & -0.007 & & 0.113 & $\star * *$ & 0.068 & & 0.048 & & -0.113 & *** \\
\hline Consultancy & 0.013 & & 0.118 & $\star \star$ & 0.076 & & 0.038 & & -0.278 & *** \\
\hline Number of observations & 1,998 & & 1,998 & & 1,988 & & 1,998 & & 1,998 & \\
\hline Pseudo $\mathrm{R}^{2}$ & 0.063 & & 0.077 & & 0.023 & & 0.116 & & 0.134 & \\
\hline
\end{tabular}

The table reports marginal effects of probit regressions with robust standard errors; * $\mathrm{p}<0.10,{ }^{* *} \mathrm{p}<0.05$, *** $\mathrm{p}<0.01$. (d) indicates dummy variables.

Source: Creative Industry Survey Austria 2008.

Creative enterprises that use inputs from other creative enterprises turn out to be significantly more capable to introduce innovations and conduct in-house $R \& D$ than creative enterprises that refrain from purchasing creative products and services from outside. This may be interpreted as a specialisation effect since using creative inputs from others allows to concentrating on ones own strengths. Team working, i.e. the establishment of a network of creative enterprises to deliver products and services jointly, affects innovation activities only in case of stable networks. These effects are limited to process innovation and imitative product innovation, while networking does not support the introduction of market novelties or R\&D. This may indicate that networks are a rather limited mean to protect intellectual property in the Creative Industries and thus have little supportive effects on the enterprises' 
choice to engage in innovative activities which demand effective knowledge protection. Flexible networking which is based on building a network of partners for each specific occasion and which implies varying partners over time does not stimulate innovation activities of creative enterprises.

A high level of employee mobility is favourable for introducing new products, including market novelties. Creative enterprises located in a university town do not seem to be helpful for a higher innovation performance - in case of market novelties it even hurts. One should note, however, that in a small country such as Austria with a rather dense network of university towns (six in total), distances from any location to the next urban centre are rather low. Nevertheless, our results show that there are no localised advantages for creative enterprises located in urban centres when it comes to the propensity to innovate. Of course, the density of creative enterprises is clearly higher in University towns than in rural areas.

Innovation activities are also strongly influenced by the sector a creative enterprise belongs to. Creative enterprises from Engineering and Software show the highest propensity to conduct R\&D, while enterprises from Architecture show the lowest probability to introduce any type of innovation. Enterprises from Design and Software are most likely to introduce product imitations.

\section{Contributing to Innovation in Other Sectors}

A main objective of this paper is to investigate the role of the Creative Industries in supporting innovation in other sectors of the economy. We analyse this issue empirically along three lines: First, we look at the contribution to innovation through demanding new technology (“upstream effects”). Secondly, we analyse to which extent creative enterprises support innovative activities of their customers, in which stages of the innovation process this support takes place, and which sectors profit from this support (“downstream effects”). Finally, we investigate the determinants that drive a creative enterprise's contribution to innovation in other sectors through both ways. 


\subsection{Descriptive Results}

Creative enterprises strongly rely on new technology. More than 90 percent of them use new technologies in their daily business (see table 4). Information and communication technologies are the most commonly used technologies in all creative industry sectors, both in terms of hardware and software. But there is also a variety of other types of new technologies demanded by the Creative Industries, from technical equipment in the music and film industry to new materials used in design fashion or performing arts. In terms of triggering innovation in the wider economy, it is important through which channels creative enterprises articulate their technology demand and access new technologies. Our survey shows that 46 percent of the creative enterprises directly contact technology producers to acquire new technology. This share is higher in Engineering, Advertising and Architecture sectors and lower in the Design and Content sectors. Direct contact is important to transfer innovation impulses from users and producers and helps technology producers to redesign their products along customer demand (see Fagerberg, 1995). 18 per cent of the creative enterprises report that new technology has been developed specifically for them. These creative enterprises provided direct innovation stimulus to technology producers. Their share is somewhat higher in the Advertising and Publishing sectors. Much of this direct technology impulses are likely to relate to software and ICT hardware.

Table 4: Use of new technology by creative enterprises

\begin{tabular}{|c|c|c|c|c|c|c|}
\hline & \multicolumn{4}{|c|}{ Use of new technology } & \multirow[b]{2}{*}{$\begin{array}{c}\text { New } \\
\text { technology } \\
\text { was explicitly } \\
\text { demanded by } \\
\text { creative } \\
\text { enterprises }\end{array}$} & \multirow[b]{2}{*}{$\begin{array}{c}\text { New } \\
\text { technology } \\
\text { was } \\
\text { specifically } \\
\text { developed for } \\
\text { creative } \\
\text { enterprises }\end{array}$} \\
\hline & Total & $\begin{array}{l}\text { ICT Hard- } \\
\text { ware }\end{array}$ & Software & $\begin{array}{c}\text { Other } \\
\text { equipment } \\
\text { and } \\
\text { material }\end{array}$ & & \\
\hline Content & 93 & 81 & 77 & 53 & 39 & 12 \\
\hline Desian & 89 & 74 & 77 & 50 & 37 & 14 \\
\hline Architecture & 90 & 74 & 86 & 37 & 50 & 19 \\
\hline Advertising & 93 & 83 & 84 & 40 & 51 & 25 \\
\hline Software & 97 & 90 & 93 & 29 & 46 & 18 \\
\hline Publishing & 86 & 75 & 78 & 43 & 45 & 24 \\
\hline $\begin{array}{l}\text { Creative Industries } \\
\text { (core) }\end{array}$ & 92 & 80 & 85 & 40 & 46 & 19 \\
\hline Consultancy & 86 & 75 & 82 & 18 & 37 & 14 \\
\hline Engineering & 90 & 76 & 77 & 40 & 54 & 21 \\
\hline $\begin{array}{l}\text { Creative Industries } \\
\text { (extended) }\end{array}$ & 91 & 79 & 83 & 37 & 46 & 18 \\
\hline
\end{tabular}

All figures show the share (percent) in the total number of creative enterprises.

Source: Creative Industry Survey Austria 2008. Weighted data. 
While demand for technology captures upstream links between the Creative Industries and their suppliers, downstream links to the Creative Industries' customers are important as well. To quantify this type of innovation link, we asked the creative enterprises whether their products and services are directly used by their customers to advance innovative activities. We restrict the analysis to customers from the business enterprise sector since we are primarily interested in the Creative Industries' contribution to industrial innovation. 46 percent of the creative enterprises claim that they provide innovation-related support to their customers. Advertising enterprises report the strongest upstream innovation links (71 percent of all creative enterprises in this sector), followed by Software, Engineering and Consultancy (table 5). Enterprises from the Architecture and Contents sectors only rarely support their customers’ innovation activities.

Table 5: Innovation support of customers from the business enterprise sector by creative enterprises

\begin{tabular}{|c|c|c|c|c|c|c|}
\hline & \multirow[t]{2}{*}{ Total } & \multicolumn{5}{|c|}{ by stages of the innovation process } \\
\hline & & $\begin{array}{c}\text { Idea } \\
\text { generation }\end{array}$ & $\begin{array}{l}R \& D, \\
\text { engineering } \\
\text { design }\end{array}$ & $\begin{array}{l}\text { Product } \\
\text { design }\end{array}$ & $\begin{array}{c}\text { Testing, } \\
\text { preparatory } \\
\text { work }\end{array}$ & $\begin{array}{l}\text { Marketing, } \\
\text { implemen- } \\
\text { tation }\end{array}$ \\
\hline Content & 24 & 16 & 6 & 16 & 7 & 15 \\
\hline Design & 42 & 24 & 7 & 34 & 7 & 24 \\
\hline Architecture & 19 & 12 & 10 & 9 & 4 & 5 \\
\hline Advertising & 71 & 45 & 12 & 48 & 16 & 53 \\
\hline Software & 63 & 32 & 24 & 24 & 26 & 37 \\
\hline Publishing & 42 & 17 & 7 & 16 & 6 & 21 \\
\hline Creative Industries (core) & 44 & 25 & 13 & 24 & 12 & 26 \\
\hline Consultancy & 48 & 33 & 17 & 19 & 17 & 31 \\
\hline Engineering & 54 & 26 & 35 & 16 & 23 & 23 \\
\hline $\begin{array}{l}\text { Creative Industries } \\
\text { (extended) }\end{array}$ & 46 & 26 & 17 & 22 & 14 & 26 \\
\hline
\end{tabular}

All figures show the share (percent) in the total number of creative enterprises.

Multiple answers for stages of the innovation process allowed.

Customers do not include public organisations and private households.

Source: Creative Industry Survey Austria 2008. Weighted data.

Innovation support by creative enterprises affects different stages of the innovation process. 26 percent of the creative enterprises contribute to very early stages by helping their customers to generate ideas for innovation. This share is particularly high among enterprises from the Advertising sector (45 percent) showing that advertising services are not only about marketing products, but go back as far as identifying market potentials for new products. 17 percent of the creative enterprises provide support to $R \& D$ and engineering design, particularly from the Engineering and Software sectors. Product design is another innovation 
activity where creative enterprises offer significant contributions, naturally from the Design sector (34 percent of all creative enterprises from this sector support innovations of their customers in the product design stage), but also from the Advertising sector. Testing innovations and providing support to preparatory work for introducing innovation is no priority of the Creative Industries' innovation support, though Software and Engineering enterprises are quite often engaged at this stage. 26 percent of the creative enterprises contribute to marketing and product launch, with particularly high shares reported for enterprises from the Advertising, Software and Consultancy sectors.

The Creative Industries support innovation in a wide variety of economic sectors (see table 6). This is in line with findings from input-output analysis on the sector distribution of purchases of creative intermediate inputs (see Bhakshi et al., 2008). Almost a quarter of the creative enterprises that contribute to innovation activities of their customers support firms from hightech manufacturing (these are the manufacturing sectors shown in table 2: chemicals, machinery, electrical, vehicles), pointing to the special role of creative inputs for industrial innovation in sectors which invest a high portion of their resources into R\&D. But creative enterprises also contribute to innovation in a number of low-tech sectors and services outside the knowledge-intensive branches such as trade, transport and tourism. 22 percent of creative enterprises supporting customer innovation contribute to innovation in other enterprises from the Creative Industries.

The creative industry sectors show very distinct sector patterns with respect to the customer branches receiving innovation support from them. Creative enterprises from the Content sector primarily serve other Creative Industries, while enterprises from the Design sector show a more widespread sector pattern, with a focus on services. Innovation support from Architecture is strongly going to the construction industry, but also a number of other branches receive contribution from this sector, e.g. for designing more efficient work places or for creating an innovative working environment. Advertising is a typical cross-sectional activity important to literally all economic sectors. Consequently, innovation support from this creative industry sector spreads over all branches without a particular focus. The same is true for Software and Publishing, though quite a number of creative enterprises from these sectors contribute to innovation in the Creative Industries. The Consultancy sector is the one with the most evenly distributed sector pattern, providing innovation support to all other 
industries. For Engineering, the situation is markedly different. Innovation support primarily goes to high-tech manufacturing and enterprises producing industrial intermediaries (such as the metal and plastics industry).

Table 6: Business customers of creative enterprises that have received innovation support from creative enterprises, by sector

\begin{tabular}{|c|c|c|c|c|c|c|c|c|c|c|c|}
\hline & \multicolumn{11}{|c|}{ Sector affiliation of customers } \\
\hline & $\begin{array}{r}\text { High- } \\
\text { tech } \\
\text { manu- } \\
\text { factu- } \\
\text { ring }\end{array}$ & $\begin{array}{r}\text { Manu- } \\
\text { factu- } \\
\text { ring of } \\
\text { consu- } \\
\text { mer } \\
\text { pro- } \\
\text { ducts }\end{array}$ & $\begin{array}{r}\text { Manu- } \\
\text { factu- } \\
\text { ring of } \\
\text { indus- } \\
\text { trial } \\
\text { inter- } \\
\text { media- } \\
\text { ries }\end{array}$ & $\begin{array}{r}\text { Manu- } \\
\text { factu- } \\
\text { ring, } \\
\text { not } \\
\text { speci- } \\
\text { fied }\end{array}$ & $\begin{array}{r}\text { Con- } \\
\text { struc- } \\
\text { tion }\end{array}$ & $\begin{array}{r}\text { Trade, } \\
\text { Trans- } \\
\text { port }\end{array}$ & $\begin{array}{l}\text { Tou- } \\
\text { rism }\end{array}$ & $\begin{array}{r}\text { Finan- } \\
\text { cial } \\
\text { inter- } \\
\text { media- } \\
\text { tion }\end{array}$ & $\begin{array}{r}\text { Crea- } \\
\text { tive } \\
\text { Indus- } \\
\text { tries }\end{array}$ & $\begin{array}{r}\text { Other } \\
\text { servi- } \\
\text { ces }\end{array}$ & $\begin{array}{r}\text { Sector } \\
\text { not } \\
\text { speci- } \\
\text { fied }\end{array}$ \\
\hline Content & 16 & 2 & 2 & 16 & 4 & 14 & 5 & 9 & 50 & 12 & 4 \\
\hline Design & 13 & 17 & 13 & 15 & 8 & 33 & 18 & 6 & 27 & 33 & 3 \\
\hline Architecture & 14 & 4 & 12 & 25 & 40 & 14 & 13 & 20 & 8 & 15 & 6 \\
\hline Advertising & 23 & 24 & 14 & 15 & 8 & 30 & 20 & 15 & 24 & 25 & 5 \\
\hline Software & 19 & 6 & 14 & 15 & 9 & 26 & 7 & 15 & 29 & 19 & 9 \\
\hline Publishing & 16 & 8 & 13 & 17 & 10 & 24 & 10 & 7 & 29 & 17 & 10 \\
\hline $\begin{array}{l}\text { Creative } \\
\text { Industries } \\
\text { (core) }\end{array}$ & 19 & 12 & 13 & 16 & 12 & 26 & 13 & 14 & 26 & 21 & 7 \\
\hline Consultancy & 24 & 11 & 21 & 29 & 10 & 28 & 10 & 25 & 20 & 23 & 13 \\
\hline Engineering & 40 & 7 & 26 & 10 & 12 & 9 & 3 & 5 & 6 & 5 & 2 \\
\hline $\begin{array}{l}\text { Creative } \\
\text { Industries } \\
\text { (extended) }\end{array}$ & 23 & 11 & 16 & 17 & 12 & 23 & 11 & 14 & 22 & 19 & 7 \\
\hline
\end{tabular}

All figures show the share (percent) of customers from a specific sector receiving innovation support from a creative enterprise in the total number of creative enterprises that support innovation activities of their customers from the business enterprise sector; note that a single creative enterprise may have supported customers from more than one sector.

Source: Creative Industry Survey Austria 2008. Weighted data.

\subsection{Determinants of innovation contributions to other sectors}

For the purpose of identifying the factors that help a creative enterprise to contributing to innovation in other firms we investigate both downstream support of innovation activities and upstream demand for new technologies in a multivariate framework. We run a further set of probit regressions, the dependent variables being the support of innovative activities at the creative enterprises' customers, differentiated by stage of innovation, as well as the demand for new technology from the creative enterprises' technology suppliers (see table 7). The explanatory variables we use in these regressions are similar to those used for investigating the drivers of innovation activities: We control for size, age and sector specific effects and determine the influence of an enterprise's creativeness, an enterprise's own innovation activities and subjects the employees graduated in. Furthermore, we add the Creative Index, 
the variables on networking with other creative enterprises and on research collaboration with Universities. What is more, we include four innovation variables: process innovation, product imitations, market novelties and in-house R\&D activities.

The key purpose of this exercise is to identify whether creative enterprises with own innovative activities are more likely to contribute to industrial innovation. With regard to downstream effects, we find a significant positive impact of $R \& D$ activities on supporting customers at early innovation stages (generation of innovation ideas, R\&D) as well as for testing innovations, but no for the design stage. Support to implementing or marketing innovations is more likely when a creative enterprise has introduced market novelties, and novel innovators also show a higher propensity to help their customers in generating ideas for innovation. One may assume learning effects here, i.e. creative enterprises that were successful in developing and introducing products and services not offered by any other firm in their market can transfer this knowledge to their customers. Market novelties will also distinguish these creative enterprises from competitors and make them a more attractive partner for industrial firms to cooperate with in innovation.

Creative enterprises that have introduced product imitations or process innovations do not show any higher propensity to support their customers' innovation efforts. The situation is clearly different when looking at upstream effects. Here any type of innovative activity by creative enterprises increases the probability to demand new technologies. Not surprisingly, process innovators show a particularly strong effect on triggering innovations by their technology suppliers indicating that new business procedures applied by creative enterprises strongly rest on the use of novel technology. The particularly strong effect for on purpose development of new technology shows that much of this technology demand is highly context specific and cannot be met by standard applications or hardware which was developed for other industries. Interestingly, creative enterprises introducing product innovations are also more likely to demand new technology, which is true for both product imitators and firms with market novelties. This result suggests that many product innovations in the Creative Industries are not purely intangible but at least rely on adaptations of technical devices and thus have some hardware component. 
Table 7: Determinants of the probability of creative enterprises to contribute to innovation in other firms: marginal effects of probit regressions

\begin{tabular}{|c|c|c|c|c|c|c|c|c|c|c|c|c|c|c|c|c|}
\hline \multirow[b]{3}{*}{ No. of employees (log) } & \multicolumn{12}{|c|}{ Support to Innovation Activities of Customers } & \multirow{2}{*}{\multicolumn{2}{|c|}{$\begin{array}{c}\text { Explicit } \\
\text { demand for } \\
\text { new } \\
\text { technologies }\end{array}$}} & \multirow{2}{*}{\multicolumn{2}{|c|}{$\begin{array}{c}\text { On purpose } \\
\text { developmen } \\
\text { of new } \\
\text { technologies }\end{array}$}} \\
\hline & \multicolumn{2}{|c|}{ All stages } & \multirow{2}{*}{\multicolumn{2}{|c|}{$\begin{array}{c}\begin{array}{c}\text { Idea } \\
\text { generation }\end{array} \\
-0.001\end{array}$}} & \multicolumn{2}{|c|}{$\begin{array}{c}\text { R\&D, } \\
\text { engineering } \\
\text { design }\end{array}$} & \multicolumn{2}{|c|}{$\begin{array}{l}\text { Product } \\
\text { design }\end{array}$} & \multicolumn{2}{|c|}{$\begin{array}{c}\text { Testing, } \\
\text { preparatory } \\
\text { work }\end{array}$} & \multicolumn{2}{|c|}{$\begin{array}{l}\text { Marketing, } \\
\text { implementation }\end{array}$} & & & & \\
\hline & 0.001 & & & & -0.001 & & -0.003 & & 0.002 & & 0.003 & & 0.036 & 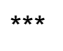 & 0.045 & $\star \star \star *$ \\
\hline Age $(\log )$ & -0.008 & & -0.010 & & -0.011 & & -0.008 & & -0.004 & & 0.016 & & -0.037 & $\star \star *$ & -0.029 & *** \\
\hline Creativity-Index & 0.027 & $\star \star$ & 0.026 & $\star \star \star *$ & 0.024 & $\star \star \star *$ & 0.023 & $\star \star \star \star ~$ & 0.004 & & 0.012 & & 0.006 & & 0.016 & $\star \star$ \\
\hline Use of creative inputs (d) & 0.106 & $\star * *$ & 0.084 & $* \star *$ & 0.008 & & 0.101 & $\star \star \star *$ & 0.012 & & 0.088 & $\star \star *$ & 0.058 & ** & 0.066 & $* \star *$ \\
\hline Stable networks (d) & 0.090 & $* * *$ & 0.081 & $\star \star \star *$ & 0.029 & & 0.058 & $* *$ & 0.049 & ** & 0.064 & $\star *$ & 0.088 & $\star \star \star *$ & 0.014 & \\
\hline Flexible networking $(d)$ & 0.118 & 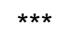 & 0.068 & ** & 0.048 & ** & 0.063 & ** & 0.037 & * & 0.058 & * & 0.091 & 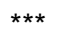 & 0.014 & \\
\hline Research projects with academia (d) & 0.082 & $\star \star$ & 0.072 & ** & 0.063 & ** & 0.031 & & 0.047 & * & 0.035 & & 0.094 & $\star \star$ & 0.050 & * \\
\hline Product imitations (d) & -0.001 & & 0.029 & & 0.033 & * & 0.021 & & 0.022 & & 0.026 & & 0.099 & $\star \star \star ~$ & 0.042 & ** \\
\hline Market novelties (d) & 0.081 & ** & 0.106 & $* \star *$ & 0.047 & * & 0.019 & & 0.036 & & 0.054 & * & 0.150 & $\star \star \star *$ & 0.101 & *** \\
\hline Process innovations (d) & 0.016 & & 0.010 & & 0.009 & & 0.025 & & 0.010 & & 0.007 & & 0.127 & 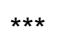 & 0.111 & 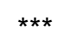 \\
\hline In-house R\&D (d) & 0.073 & ** & 0.065 & ** & 0.085 & $\star \star \star *$ & 0.033 & & 0.050 & $\star \star \star *$ & 0.042 & & 0.068 & $\star \star$ & 0.040 & $\star \star$ \\
\hline \multicolumn{17}{|c|}{ Academic subjects of graduated employees (d) } \\
\hline Natural science & -0.127 & ** & -0.112 & $* \star *$ & -0.051 & * & -0.078 & ** & -0.042 & & -0.107 & ** & -0.005 & & 0.043 & \\
\hline Engineering & 0.043 & & 0.041 & & 0.043 & * & 0.017 & & 0.051 & $\star *$ & 0.034 & & -0.019 & & -0.016 & \\
\hline Maths/computer science & 0.124 & $\star \star *$ & 0.016 & & 0.111 & $\star \star *$ & 0.055 & & 0.068 & $\star *$ & 0.082 & $\star \star$ & -0.047 & & -0.037 & \\
\hline Design & -0.027 & & 0.016 & & -0.011 & & 0.044 & & -0.012 & & -0.048 & & 0.053 & & 0.074 & ** \\
\hline Law/business/economics & 0.055 & * & 0.006 & & 0.005 & & -0.016 & & 0.039 & $\star *$ & 0.084 & $\star \star \star *$ & -0.014 & & 0.015 & \\
\hline Journalism/social sciences & -0.019 & & -0.029 & & -0.044 & & -0.035 & & -0.002 & & -0.041 & & 0.005 & & 0.043 & \\
\hline Humanities/cultural sciences & -0.056 & & -0.025 & & -0.048 & & -0.009 & & -0.007 & & -0.009 & & -0.065 & & -0.026 & \\
\hline \multicolumn{17}{|l|}{ Sectors (reference: Engineering) (d) } \\
\hline Design & -0.050 & & 0.006 & & -0.116 & $\star \star \star *$ & 0.215 & $\star \star * \star$ & -0.087 & $\star \star \star *$ & 0.058 & & -0.118 & ** & -0.025 & \\
\hline Content & -0.237 & $\star * *$ & -0.089 & $\star \star *$ & -0.141 & $\star \star \star *$ & 0.011 & & -0.099 & $\star \star \star *$ & -0.053 & & -0.110 & ** & -0.068 & ** \\
\hline Architecture & -0.306 & $* * *$ & -0.137 & $\star \star \star *$ & -0.119 & $\star \star \star *$ & -0.087 & $\star \star$ & -0.115 & $\star \star \star *$ & -0.195 & $\star \star *$ & 0.054 & & 0.020 & \\
\hline Advertising & 0.209 & 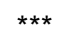 & 0.178 & $\star \star \star *$ & -0.102 & $\star \star \star *$ & 0.331 & $\star \star \star \star ~$ & -0.027 & & 0.345 & $\star \star \star$ & -0.043 & & -0.011 & \\
\hline Software & 0.096 & $\star \star$ & 0.035 & & -0.063 & $\star \star \star *$ & 0.073 & * & 0.016 & & 0.151 & $\star \star \star *$ & -0.038 & & -0.004 & \\
\hline Publishing & -0.038 & & 0.074 & * & -0.078 & $\star \star \star *$ & 0.065 & & -0.039 & & 0.106 & $\star \star$ & -0.154 & 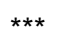 & -0.061 & $\star *$ \\
\hline Consultancy & -0.091 & & -0.088 & * & -0.112 & $\star \star \star \star ~$ & 0.033 & & -0.084 & 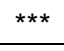 & -0.007 & & -0.067 & & 0.008 & \\
\hline Number of observations & 1,998 & & 1,998 & & 1,998 & & 1,998 & & 1,998 & & 1,998 & & 1,998 & & 1,998 & \\
\hline Pseudo $\mathrm{R}^{2}$ & 0.140 & & 0.098 & & 0.138 & & 0.111 & & 0.112 & & 0.150 & & 0.082 & & 0.151 & \\
\hline
\end{tabular}


The degree of an enterprise's creativeness positively influences the contribution to innovation in other firms in the early stages of the innovation process, including the product design stage. Creativeness is not important for later stages such as testing or launching innovations, however. The index of creativeness is also not significant for the demand of new technologies but is significant for the use of new technologies which are specifically developed for the creative enterprise. Creative enterprises that use networking within the Creative Industries are more likely to support industrial innovation. This effect is particularly strong for using creative inputs, though restricted to the idea, design and implementation/marketing stages. Since these three stages are those for which inputs from the Creative Industries are particularly typical, it suggests that creative enterprises that focus their resources are more capable to provide valuable innovation inputs to others.

Team working has more widespread effects since creative enterprises engaged in networks with other creative enterprises show a higher propensity to support their customers' innovation activities in all stages of the innovative process. This result holds for both stable and flexible networking. Research cooperation with Universities shows a similar impact as inhouse $R \& D$, though both variables are not strongly correlated with each other. This rather suggests that investing into $R \& D$ or accessing University knowledge both result in a type of knowledge and competence at the side of creative enterprises that can be utilised by other firms for generating innovation ideas, conducting R\&D or testing innovations.

With regard to other model variables, there are almost no size and age effects, except for explicitly demanding new technologies from technology suppliers, which increases by size, but decreases by age. Technical academic skills are especially relevant for R\&D support and testing innovations, while not relevant for generating ideas or product design. Creative enterprises with graduates with a background in economics, business administration or law are more likely to support later stage innovation activities of their customers. There are no effects from graduates in the fields of design, social sciences or humanities and the arts compared to creative enterprises without graduated employees. The significance of the sector dummies confirm the descriptive findings shown in table 7. Advertising firms focus on innovation support in the form of generating ideas, product design and marketing or product launching. Consultancy focuses on generating ideas and product launching, too, while R\&D support and testing is dominated by engineering firms. 


\section{Conclusion: How Innovation Policy May Strengthen the Creative Industries’ Contribution to Industrial Innovation}

The paper analysed the role of the Creative Industries in industrial innovation. We conducted a survey of more than 2,000 “creative enterprises" from Austria, i.e. enterprises from creative industry sectors that produce and deliver products and services in a creative way. We explored both the innovation performance of these enterprises and their links to innovation in other sectors, considering both upstream and downstream links.

Survey results show that the Creative Industries are among the most innovative sectors, even with regard to standard measures on innovative performance which were developed to capture industrial innovation, such as the share of $R \& D$ performing enterprises or the share of enterprises introducing market novelties. Most creative enterprises support innovation by demanding new technology, especially ICT, and by helping their customers to innovate. They are partners in various stages of industrial innovation processes, from idea generating to marketing of new products, and they contribute to innovation in a great variety of economic sectors.

Given this role of the Creative Industries in industrial innovation, innovation policy may want to further advance their contribution to innovation in the wider economy. Our findings have a number of implications for such a policy objective. First, own innovative efforts of creative enterprises are important for contributing to other firms' innovation activities. This is particularly true for in-house $R \& D$ and for introducing novel product innovations. One may read this as other enterprises' demand for "original creativity” which should complement their own creative efforts. Creative enterprises are thus the more attractive as partners in innovation projects the more they can offer creative inputs that are novel. Secondly, networking among creative enterprises clearly helps to support innovation in the wider economy. Networking here means to purchase creative input from other creative enterprises and to develop, produce and deliver products and services jointly with other creative enterprises. Both strategies facilitate specialisation and allow creative enterprises to focus on their comparative advantages. Using complementary inputs from other creative enterprises is also helpful to offer a bundle of different creative products and services, which is likely to be more relevant for supporting industrial innovation (e.g. through combining advertising, photography, film, 
graphic design and consultancy services to offer an integrated service for marketing new products).

Strengthening the Creative Industries' contribution to industrial innovation means to strengthen their capability to innovate. Our analysis shows that innovative efforts are driven, among others, by human capital and networking. Stimulating the employment of graduates and promoting networking among creative enterprises are two promising policy approaches. For increasing the number of graduated employees one may opt for either providing incentives to creative enterprises to hire academic staff or stimulating entrepreneurship among graduates. Cluster approaches (see Pratt, 2004b) can help intensifying ties among creative enterprises and reduce transaction costs of collaboration.

Another driver for own innovative efforts as well as for initiating innovation at the Creative Industries' technology suppliers is firm size. Larger creative enterprises clearly have advantages in conducting in-house R\&D and introducing innovations. One has to interpret this result against the fact that 35 percent of all creative enterprises covered in our survey are sole traders, and the median of the number of employees (including firm owners) is 3 . Promoting growth of creative enterprises, particularly by providing incentives to sole traders and very small firms to take on workers would be a policy option to increase firm size in this sector. Temporary tax incentives for enterprises hiring additional labour could be a policy instrument in this case.

Any policy targeted at the Creative Industries will have to deal with the substantial heterogeneity of this sector, meaning that policy measures should consider the specific situation for innovation and innovation spillovers within the different Creative Industry sectors. The Advertising and Software sectors show particularly close ties to industrial innovation activities, as do the Consultancy and Engineering sectors, which are often not considered as part of the Creative Industry though they share many characteristics with the “core" sectors. The Architecture and Content sectors have rather little links to innovation activities of their customers, and contribution to innovation at their customers is concentrated on the construction business (in case of Architecture) and on other Creative Industry sectors (in case of Content). In contrast, Advertising, Design and Consultancy support a wide variety of customer sectors, while Software focuses on services sectors, and Engineering on manufacturing. 
The Creative Industries are also confronted with a number of constraints that may impede the full realisation of their creative potentials. In our survey, we also investigated the relevance of various obstacles for realising business ideas and utilising the full growth potential of the firm. 36 percent of the creative enterprises reported such constraints. Two obstacles turned out to be particularly relevant. First, a lack of time was mentioned as the most important constraint by 15 percent of the creative enterprises, and 13 percent claimed a lack of financial sources. Lack of time is clearly linked with the small size of many enterprises, resulting in a high workload on the firm owner and the very small number of other personnel. When balancing between day-to-day business and pursuing new ideas, the latter often falls short. Lack of financial sources is another typical constraint for innovation in very small firms, since many innovation projects demand minimum investment in terms of personnel resources and investment in equipment. While the available cash-flow may be too small to fund such investment, it will be very difficult for creative enterprises to obtain external funding from banks or private equity. Banks are often faced with information asymmetries about the market potential of innovative ideas since they are rarely familiar with this specific type of business. In addition, most innovative activities in the Creative Industries involve little or no fixed investment, thus restricting the availability of collaterals. For the private equity business, almost all creative enterprises are much too small to make them an attractive investment object. Direct public support to innovation activities in the Creative Industries is certainly a way how policy can overcome these constraints.

\section{References}

Acs, Z.J., D. B. Audretsch (1988), Innovation in Large and Small Firms: An Empirical Analysis, American Economic Review 78, 678-690.

Acs, Z.J., D. B. Audretsch (1991), Innovation and Size at the Firm Level, Southern Economic Journal 57, 739-744.

Almus, M., D. Engel, S. Prantl (2000), The ZEW Foundation Panels and the Mannheim Enterprise panel (MUP) of the Centre for European Economic Research (ZEW), Schmollers Jahrbuch 120, 310-308.

Andari, R., H. Bakhshi, W. Hutton, A. O’Keeffe, P. Schneider (2007), Staying Ahead: The economic performance of the UK's Creative Industries, The Work Foundation, London. 
arge creativ wirtschaft austria (2008), Dritter österreichischer Kreativwirtschaftsbericht, Austrian Chamber of Commerce, arge creativ wirtschaft austria, Vienna.

Bakhshi, H., E. McVittie, J. Simmie (2008), Creating Innovation. Do the creative industries support innovation in the wider economy? NESTA Research Report March 2008, London.

Beise, M. (2004), Lead Markets: Country-specific Drivers of the Global Diffusion of Innovations, Research Policy 33, 997-1018.

Bhattacharya, M., H. Bloch (2004), Determinants of Innovation, Small Business Economics 22, 155-162.

Brüderl, J., P. Preisendörfer (1998), Network Support and the Success of Newly Founded Business, Small Business Economics 10, 213-225.

Cooke, P., D. Schwartz (2007), Creative Regions: Technology, Culture and Knowledge Entrepreneurship, Routledge, London.

Chesbrough, H. (2003), Open Innovation: The New Imperative for Creating and Profiting from Technology, Harvard Business School Press, Boston.

Cohen, W.M. (1995), Empirical Studies of Innovative Activity, in: P. Stonemann (ed.), Handbook of the Economics of Innovation and Technical Change, Blackwell, Oxford, 182264.

Cohen, W.M., S. Klepper (1996), Firm Size and the Nature of Innovation within Industries: The Case of Process and Product R\&D, The Review of Economics \& Statistics 78, 232-243.

Cohen, W.M., D.A. Levinthal (1989), Innovation and Learning: The Two Faces of R\&D, The Economic Journal 99, 569-596.

Cohen, W.M., D.A. Levinthal (1990), Absorptive Capacity: A New Perspective on Learning and Innovation, Administrative Science Quarterly 35, 128-152.

Crepon, B., E. Duguet, J. Mairesse (1998), Research and development, innovation and productivity: An econometric analysis at the firm level, Economics of Innovation and New Technology 7, 115-158.

DCMS (1998), Creative Industries - Mapping Document, Department for Culture, Media and Sport, London.

European Commission (2006), Economy of Culture in Europe, DG Education and Culture, Brussels.

Experian (2007), How linked are the UK's creative industries to the wider economy? An input-output analysis, NESTA Working Paper, London.

Fagerberg, J. (1995), User-Producer Interaction, Learning and Comparative Advantage, Cambridge Journal of Economics 19, 243-256.

Florida, R. (2002), The Rise of the Creative Class. And How It's Transforming Work, Leisure and Everyday Life, Basic Books. 
Frontier Economics (2006), Comparative Analysis of the UK's Creative Industries, Reports to DCMS, London.

Galenson, D.W. (2006), Analyzing Artistic Innovation: The Greatest Breakthroughs of The Twentieth Century, NBER Working Paper No. 12185, Cambridge, MA.

Georgieff, P., S. Kimpeler, K. Müller, C. Rammer (2008), Beitrag der Creative Industries zum Innovationssystem am Beispiel Österreichs, Endbericht zur Studie im Auftrag der Wirtschaftskammer Österreich - arge creativ wirtschaft austria, Karlsruhe and Mannheim.

Green, L., I. Miles, J. Rutter (2007), Hidden Innovation in the Creative Industries, NESTA Working Paper, London.

Handke, C.W. (2004), Measuring Innovation in Media Industries: Insights from a Survey of German Record Companies, Humboldt-University, Berlin and Erasmus University, Rotterdam.

Handke, C.W. (2006), Surveying innovation in the creative industries, Humboldt-University, Berlin and Erasmus University, Rotterdam.

Higgs, P., S. Cunningham, H. Bakhshi (2008), Beyond the creative industries: mapping the creative economy in the United Kingdom, NESTA, London.

Huergo, E., J. Jaumandreu (2004), How Does Probability of Innovation Change with Firm Age? Small Business Economics 22, 193-207.

Laursen, K., A. Salter (2006), Open for Innovation: The Role of Openness in Explaining Innovation Performance among U.K. Manufacturing Firms, Strategic Management Journal 27, 131-150.

Leiponen, A. (2005), Skills and innovation, International Journal of Industrial Organization 23, 303-323.

Miles, I., L. Green (2008): Hidden innovation in the creative industries, NESTA Research Report, London.

OECD (2002), Frascati Manual 2002: Proposed Standard Practice for Surveys on Research and Experimental Development, OECD, Paris.

OECD (2005), Oslo Manual: Guidelines for Collecting and Interpreting Innovation Data, $3^{\text {rd }}$ edition, OECD, Paris.

OECD (2006), International Measurement of the Economic and Social Importance of Culture, OECD, Paris.

Pratt, A. (2004a), The cultural economy: A call for spatialized 'production of culture' perspectives, International Journal Of Cultural Studies 7, 117-128.

Pratt, A. (2004b), Creative Clusters: Towards the Governance of the Creative Industries Production System? Media International Australia incorporating Culture and Policy 112, 5066.

Scott, A.J. (2000), The Cultural Economy of Cities, Sage, London. 
Stoneman, P. (2007), An introduction to the definition and measurement of soft innovation, NESTA working paper, London.

Van Dijk, B., R. Den Hertog, B. Menkveld, R. Thurik (1997), Some New Evidence on the Determinants of Large- and Small-Firm innovation, Small Business Economics 9, 335-343.

Von Hippel, E. (1988), The Sources of Innovation, Oxford University Press, New York.

Wilkinson, A. (2007), An Assessment of Productivity Indicators for the Creative Industries, DCMS, London. 


\section{Appendix}

Table A1: Descriptive statistics on model variables of probit regressions in chapter 4 and 5

\begin{tabular}{|c|c|c|}
\hline Variable & Mean & Std. Dev \\
\hline No. Of Employees (log) & 1.213 & 1.209 \\
\hline Age $(\log )$ & 2.318 & 0.787 \\
\hline Creativity-Index & 3.142 & 1.140 \\
\hline Use of creative inputs & 0.558 & 0.497 \\
\hline Stable networks & 0.421 & 0.494 \\
\hline Flexible networking & 0.378 & 0.485 \\
\hline Research projects with academia & 0.143 & 0.350 \\
\hline Share of graduated employees & 0.308 & 0.375 \\
\hline Located in a University town & 0.461 & 0.499 \\
\hline Employee mobility & 0.554 & 0.978 \\
\hline \multicolumn{3}{|l|}{ Innovation indicators } \\
\hline Product imitation & 0.383 & 0.486 \\
\hline Market novelties & 0.218 & 0.413 \\
\hline Process innovation & 0.509 & 0.500 \\
\hline In-house R\&D & 0.321 & 0.467 \\
\hline \multicolumn{3}{|l|}{ Contributing to innovation in other firms } \\
\hline Innovation support (all stages) & 0.476 & 0.500 \\
\hline Innovation support (idea stage) & 0.274 & 0.446 \\
\hline Innovation support (R\&D stage) & 0.165 & 0.371 \\
\hline Innovation support (design stage) & 0.231 & 0.422 \\
\hline Innovation support (testing stage) & 0.151 & 0.358 \\
\hline Innovation support (implementation stage) & 0.288 & 0.453 \\
\hline Use of new technologies specifically demanded by the creative enterprise & 0.452 & 0.498 \\
\hline Use of new technologies specifically developed for the creative enterprise & 0.187 & 0.390 \\
\hline \multicolumn{3}{|l|}{ Sectors } \\
\hline Design & 0.094 & 0.291 \\
\hline Content & 0.096 & 0.295 \\
\hline Architecture & 0.157 & 0.364 \\
\hline Advertising & 0.151 & 0.358 \\
\hline Software & 0.159 & 0.365 \\
\hline Publishing & 0.055 & 0.228 \\
\hline Consultancy & 0.154 & 0.361 \\
\hline Engineering & 0.136 & 0.342 \\
\hline \multicolumn{3}{|l|}{ Academic subjects of graduated employees } \\
\hline Natural science & 0.054 & 0.225 \\
\hline Engineering & 0.176 & 0.381 \\
\hline Maths/computer science & 0.093 & 0.291 \\
\hline Design & 0.114 & 0.318 \\
\hline Law/business/economics & 0.234 & 0.423 \\
\hline Journalism/social sciences & 0.084 & 0.278 \\
\hline Humanities/cultural sciences & 0.078 & 0.268 \\
\hline
\end{tabular}

Source: Creative Industry Survey Austria 2008. 